\title{
Comments on 'No K/T boundary at Anjar, Gujarat, India: Evidence from magnetic susceptibility and carbon isotopes'
}

\author{
by $\mathrm{H}$ J Hansen, D M Mohabey and P Toft \\ (Proc. Indian Acad. Sci. (Earth Planet Sci.), 110, June 2001, 133-142) \\ A D SHuKLA* and P N Shukla \\ Physical Research Laboratory, Ahmedabad 380 009, India \\ *e-mail: anilds@prl.ernet.in
}

Based on magnetic susceptibility and $\delta^{13} \mathrm{C}_{\text {org }}$ data Hansen et al (2001) have argued that K/T boundary does not exist in Anjar intertrappean sediment section in the Deccan trap province. The $\mathrm{K} / \mathrm{T}$ boundary is commonly identified by the disappearance of Cretaceous index fossil (e.g., Micula prinsii), in association with geochemical and geochronological markers. The geochemical and mineralogical signatures include Ir anomaly, shocked quartz, Ni-rich spinels, micro-diamonds, fullerenes, amino acids and more recently identification of nano-size phases of iron has been added to this list for identification of extinction horizons. At Anjar, the presence of iridium enrichment in three ferruginous bands of intertrappean sediments (Bhandari et al 1995, 1996), association of fullerenes (Parthasarthy et al 2000) and nano-size iron phases in these bands (Bhandari et al 2000) strongly suggest the existence of the $\mathrm{K} / \mathrm{T}$ boundary horizon. Besides these well established criteria, the age of intertrappean sediments is well constrained, both by the ${ }^{39} \mathrm{Ar}-{ }^{40} \mathrm{Ar}$ ages of the overlying and underlying flows (Venkatesan et al 1996) and the palaeomagnetic stratigraphy, which suggest their deposition during 29R (Shukla et al 2001a).

The dissimilar nature of magnetic susceptibility profile in Anjar compared to other $\mathrm{K} / \mathrm{T}$ sections such as El Kef section, Tunisia, and the absence of the negative shift in $\delta^{13} \mathrm{C}_{\text {org }}$ profile in Anjar has been advocated as reasons for the absence of $\mathrm{K} / \mathrm{T}$ boundary by Hansen et al (2001). Unfortunately, both of these signatures are not unique characteristics of the $\mathrm{K} / \mathrm{T}$ boundary. Variation in magnetic susceptibility $(\chi)$ has been used as indicator of KTB by the authors without providing any physical basis for the same. In view of the fact that variation in $\chi$ can be caused by a variety of factors such as soil formation, presence of authigenic magnetite/goethite, fly and volcanic ash deposits, it is essential to suggest the causative mechanism for the enhancement of $\chi$ at the KTB. The early work on the $\mathrm{K} / \mathrm{T}$ sections from Petriccio, Italy and in DSDP sites by Worm and Banerjee (1987) using magnetic susceptibility data, suggests a magnetic anomaly at $\mathrm{K} / \mathrm{T}$ boundary due to the presence of black magnetic microspherules which are believed to be of impact melt origin. However, their affect can hardly be seen in shale deposit which themselves have magnetic materials.

Anjar intertrappean sediments are lacustrine deposits formed during semi-arid conditions proximal to fluctuating coastline (Khadkikar et al 1999). These sediments also have volcanogenic clay minerals derived from the weathering of nearby flows. The Deccan flows, with abundant magnetic minerals, e.g., titanomagnetite, can supply these minerals to the intertrappeans, and thereby influence the magnetic susceptibility of the sediments and 
therefore, their profiles may have no relevance to KTB.

The negative shift in $\delta^{13} \mathrm{C}_{\text {org }}$ profile associated with $\mathrm{K} / \mathrm{T}$ transition and attributed to forest fire, may not coincide exactly with the extinction horizon as the preservation of carbon bearing sediments involve many geochemical processes. Indeed, Hansen et al (1996) have mentioned that $\delta^{13} \mathrm{C}_{\text {org }}$ profile exhibits some delay with respect to the exact extinction horizon in the typical $\mathrm{K} / \mathrm{T}$ section at El Kef, Tunisia. At Anjar, the authors do not find a negative shift in $\delta^{13} \mathrm{C}_{\text {org }}$, which could be due to the absence of C3 plants during the KTB event. The palaeoenvironmental reconstruction attempted by Khadkikar et al (1999), suggested the prevalence of semi-arid to 'mock aridity' type of climate condition at Anjar. Thus, it is expected that under such climate, the stress loving plant community would thrive which will have less negative $\delta^{13} \mathrm{C}_{\text {org }}$ (plants having C-4 type photosynthesis pathway).

Bhandari et al (1993) reported absence of iridium anomaly from Deccan flows (Ir concentration $\leq 0.027 \mathrm{ppb})$ and intertrappeans at various locations, e.g., Takali, Chui hill, Padwar, Bargi Canal and Jirabad (Ir concentration range from 0.008 to $0.12 \mathrm{ppb}$ ) with the sole exception of Anjar (Bhandari et al 1995). Rocchia et al (1988) have also reported absence of iridium enhancement in both the flows and intertrappean sediments at several locations in the Deccan Province. Although all the characteristic palaeontological or geochemical evidences are absent, the authors find a susceptibility change and $\delta^{13} \mathrm{C}_{\text {org }}$ excursion pattern at Chui hill and attributed them to $\mathrm{K} / \mathrm{T}$ boundary.

The authors further argue that there is causal relationship between the iridium enrichment and associated clay layers, which could be rhyolitic bentonites. The flows in the Anjar area are alkali basalts having affinity to Ocean Island Basalts such as Réunion basalts (Shukla et al 2001a) and are not rhyolitic. The iridium contribution from these flows (Ir concentration range between 2 and 178 ppt) is not sufficient for the observed iridium anomaly (Shukla et al 2001b). Considering the ages of underlying flows $(65.1 \pm 0.5 \mathrm{Ma})$ and overlying flows $(65.4 \pm 0.6 \mathrm{Ma})$ together with palaeomagnetic stratigraphy Shukla et al (2001a) suggest the deposition of iridium around KTB event.

The assertion of the authors that no $\mathrm{K} / \mathrm{T}$ boundary exists at Anjar is also influenced by report of the presence of dinosaur fossils above the upper iridium rich layer (Bajpai and Prasad 2000). Fragmentary nature of fossil pieces and eggs of dinosaurs above the upper iridium layer may indicate their presence in secondary context as no big bones have been found. The lithostratig- raphy of the Anjar lake sediments (Shukla et al 1997) has been reconstructed by partially overlapping sedimentary horizons along the hill slope in the absence of any marker bed and therefore such a stratigraphic correlation is fraught with uncertainty. However, one spectacular sedimentary structure viz., the lenticular cherty limestone horizon above the upper most iridium layer suggests that during the deposition of iridium in the shale horizon environment was initially calm and became turbulent after this event. The lenticular bedding requires current or wave action, preferably in a tidal environment. The possibility of local reworking of fossils from the preexisting fossil beds or from the surrounding area without any significant modification cannot be ruled out. Therefore, drawing any conclusion that there is no KTB at Anjar, without a detailed supporting sedimentological analysis of the basin sediments, is erroneous. The similarity in the ages of overlying and underlying flows within errors indicate that the time available for deposition of about $6 \mathrm{~m}$ of sediments could be too short $(<1 \mathrm{Ma})$ for the development of Palaeocene fossils. We would like to emphasize that the three independent geochemical markers like iridium, fullerenes and nano-size particles together with geochronological constraints support the preservation of impact records of KTB at Anjar.

In summary, we would like to point out that one cannot ignore the presence of iridium anomaly, fullerenes and associated nano-meter size particles in Anjar while interpreting the magnetic susceptibility profile and $\delta^{13} \mathrm{C}_{\text {org }}$ data. The conclusion that there is no $\mathrm{K} / \mathrm{T}$ boundary at Anjar based on magnetic susceptibility and $\delta^{13} \mathrm{C}_{\text {org }}$ criteria developed by Hansen et al (2001) ignore the overwhelming geochemical and geochronological evidences and appear erroneous. Independent work of enhanced iridium and the geochronological and palaeomagnetic framework obtained by the French group (Courtillot et al 2000) amply prove the presence of KTB at Anjar. In our opinion, the paper by Hansen et al should have been titled " $\mathrm{K} / \mathrm{T}$ boundary at Anjar: No evidence from magnetic susceptibility and $\delta^{13} \mathrm{C}_{\text {org }}$ excursion pattern" rather than the other way around.

\section{References}

Bajpai S and Prasad G V R 2000 Cretaceous age for Ir rich Deccan intertrappean deposits: palaeontological evidence from Anjar western India; J. Geol. Soc. London $157257-$ 260

Bhandari N, Shukla P N, Ghevariya Z G and Sundaram S M 1995 Impact did not trigger Deccan volcanism: Evidence from Anjar K/T boundary intertrappean sediments; Geophys. Res. Lett. 22 433-436 
Bhandari N, Shukla P N, Ghevariya Z G and Sundaram S M $1996 \mathrm{~K} / \mathrm{T}$ boundary layer in Deccan intertrappeans at Anjar, Kutch; Geol. Soc. Am. Spec. Pap. 307 417-424

Bhandari N, Verma H C, Upadhyay C, Tripathi A and Tripathi R P 2000 Mössbauer Spectroscopy of K/T boundary clays: Characteristics of iron bearing minerals; In: Catastrophic events and mass extinctions: Impacts and beyond, p 12-13, LPI Contribution No. 1053 (Houston: Lunar and Planetary Institute)

Bhandari N, Shukla P N and Castagnoli G C 1993 Geochemistry of some K/T sections in India; Palaeogeography, Palaeoclimatology, Palaeoecology 104 199-211

Courtillot V, Gallet Y, Rocchia R, Feraud G, Robin E, Hofmann and Bhandari N 2000 Cosmic markers, ${ }^{40} \mathrm{Ar} /{ }^{39} \mathrm{Ar}$ dating and paleomagnetism of the $\mathrm{K} / \mathrm{T}$ sections in the Anjar area of the Deccan Large Igneous Province; Earth Planet. Sci. Lett. 182 137-156

Hansen H J, Mohabey D M and Toft P 2001 No K/T boundary at Anjar, Gujarat, India: Evidence from magnetic susceptibility and carbon isotopes; Proc. Indian Acad. Sci. (Earth Planet Sci.) 110 No. 2, 133-142

Hansen H J, Toft P, Mohabey D M and Sarkar A 1996 Lameta age: dating the main pulse of the Deccan traps volcanism; Gondwana Geol. Mag. Spl. Vol. 2 365-374

Khadkikar A S, Sant D A, Gogte V and Karanth R V 1999 The influence of Deccan volcanism on climate: Insights from lacustrine intertrappean deposits, Anjar, western India; Palaeogeography, Palaeoclimatology, Palaeoecology 147 141-149
Parthasarthy G, Bhandari N, Vairamani M, Kunwar A C and Narasaih B 2000 Natural Fullerenes from the K-T Boundary Layer at Anjar, Kutch, India; In: Catastrophic events and mass extinctions: Impacts and beyond, $\mathrm{p} 12$ 13, LPI Contribution No. 1053 (Houston: Lunar and Planetary Institute)

Rocchia R, Boclet D, Courtillot V and Jaeger J J 1988 A search for iridium concentration in Deccan traps and intertraps; Geophys. Res. Lett. 15 812-815

Shukla A D, Bhandari N, Kusumgar S, Shukla P N, Ghevariya Z G, Gopalan K and Balram V 2001a Geochemistry and magnetostratigraphy of Deccan flows at Anjar, Kutch; Proc. Indian Acad. Sci. (Earth Planet Sci.) 110 No. 2, 110-132

Shukla P N, Bhandari N, Das A, Shukla A D and Ray J S 2001b High iridium concentration of alkaline rocks of Deccan and implications to K/T boundary; Proc. Indian Acad. Sci. (Earth Planet Sci.) 110 No. 2, 103-110

Shukla P N, Shukla A D and Bhandari N 1997 Geochemical characterization of the Cretaceous-Tertiary boundary sediments at Anjar, India; Palaeobotanist 46 (1,2) 127132

Venkatesan T R, Pande K and Ghevariya Z G $1996{ }^{40}$ Ar${ }^{39} \mathrm{Ar}$ ages of Anjar Traps, western Deccan Province (India) and its relation to Cretaceous-Tertiary boundary events; Curr. Sci. 70 990-996

Worm H U and Banerjee S K 1987 Rock magnetism signature of the Cretaceous-Tertiary boundary; Geophys. Res. Lett. 14 No. 11 1083-1086 